\title{
A Rare Cause of Acute Abdomen: Appendiceal Neuroma
}

\section{Akut Karının Nadir Bir Nedeni: Apendikal Nöroma}

Mehmet Tolga Kafadar ${ }^{1}$, Gurkan Degirmencioglu²

${ }^{1}$ Health Sciences University Mehmet Akif Inan Training and Research Hospital Clinic of General Surgery, Şanlıurfa, Turkey ${ }^{2}$ Kırıkhan State Hospital Clinic of General Surgery, Hatay, Turkey

Geliş Tarihi/Received: 06 July 2015 Kabul Tarihi/Accepted: 16 September 2015

\begin{abstract}
$\ddot{O z}$
Akut karın nedeniyle acil birimlere başvuran hastalarda en sık cerrahi müdahale sebebi akut apandisittir. Akut apandisitin patofizyolojisinde apendiks lümenindeki obstrüksiyonun başlatıcı neden olduğu yaygın olarak kabul görmüştür. Çoğunlukla apendiksin lümenine bazı gıda ve dışkı artıklarının girmesi, bunlarla tıkanması ve bölgede lenf bezlerinin iltihaplanarak şişmesi sonucu meydana gelir. Lümenin obstrüksiyonu bakterilerin aşırı çoğalmasına, mukus sekresyonunun artmasına ve intraluminal basıncın artmasına yol açar. Son yıllarda patofizyolojide nöral komponentin varlığının ileri sürüldüğü çalışmalar da bulunmaktadır. Bunlar oblitere apendiks, fibröz obliterasyon, apendikal nöroma, nörojenik apandisit gibi tanılarla karşımıza çıkabilmektedir. Bu yazıda, akut karının nadir görülen bir nedeni olan, apandisit ön tanısıyla apendektomi uygulanan ve histopatolojik olarak apendikal nöroma tanısı alan bir olguyu sunduk.
\end{abstract}

Anahtar Kelimeler: Akut karın, apendektomi, apendikal nöroma

\begin{abstract}
Acute appendicitis is the most common indication for surgical intervention in patients presenting to emergency department with acute abdomen. Obstruction of appendiceal lumen has been widely accepted as the precipitating factor in the pathophysiology of acute appendicitis. It usually develops as a result of food or feces particles entering into and obstructing appendiceal lumen, leading to inflammation and swelling of regional lymph nodes. Luminal obstruction results in overproduction of bacteria, excessive mucus secretion, and increased intraluminal pressure. Some studies in recent years have suggested a neural component in the pathophysiology of this condition. Such cases may present with various diagnoses such as obliterated appendix, fibrous obliteration, appendiceal neuroma, and neurogenic appendicitis. In this paper we present a case operated with the initial diagnosis of appendicitis and histopathologically diagnosed with appendiceal neuroma, a rare cause of acute abdomen.
\end{abstract}

Keywords: Acute abdomen, appendectomy, appendiceal neuroma

\section{INTRODUCTION}

Acute abdomen refers to all nontraumatic pathological conditions characterized by abdominal pain, signs and symptoms of which are concentrated in the abdominal region. The cause of the pain is an intraabdominal pathology requiring urgent surgical operation in most cases. It is widely accepted that obstruction of appendiceal lumen is the initiating factor in the pathophysiology of acute appendicitis (1). Some recent studies also pointed to a neural component in the pathophysiology. There is a general agreement that repeated mild inflammatory attacks cause the proliferation of the neuroendocrine cells found in the appendiceal stroma, leading to clinical picture of acute appendicitis (2). Herein, we report a case operated for a rare cause of acute abdomen and histopathologically diagnosed with appendiceal neuroma.

\section{CASE REPORT}

A 35-year-old man was admitted to emergency department with abdominal pain and loss of appetite for 2 days. His past history was notable for a thoracotomy operation for left spontaneous pneumothorax about 3 months ago; he had no problem at the postoperative period. He had no other disease. On physical examination he had tenderness on palpation, guarding, and rebound 
tenderness at lower right abdominal quadrant but he had no fever. Laboratory tests revealed a white blood cell count of $8300 / \mathrm{mm}^{3}$ and a CRP level of $18.5 \mathrm{mg} / \mathrm{L}$. No abnormality was noted in upright plain abdominal roentgenogram. His whole abdomen ultrasonography showed increased calibration of appendix vermiformis with the greatest diameter of $11 \mathrm{~mm}$; its wall was markedly edematous and there was minimal abdominal free fluid. With the signs and symptoms suggestive of acute abdomen, the patient was taken to operation room with an initial diagnosis of appendicitis. Upon observing during surgery that appendix vermiformis was erectile, edematous, and hyperemic, acute appendicitis was confirmed and appendectomy was applied with no additional surgical intervention. The patient was discharged with full recovery 2 days later. Subsequently, the pathology report showed an appendiceal neuroma (Figure 1).

\section{DISCUSSION}

Acute abdomen is a clinical condition characterized by abdominal pain of sudden onset. Acute appendicitis is the most common surgical pathology in patients presenting to emergency department with abdominal pain. Although the mortality and morbidity of this condition have been dramatically reduced than previous years, it is a cause of acute abdomen, differential diagnosis of which is still difficult. It is more common between 15 and 25 years of age (1).

Acute appendicitis is mainly diagnosed based on patient history and physical examination. Elevated white blood cell count and C-reactive protein, and appendicitis-specific signs on ultrasonography may aid in the diagnostic process. Unfortunately, these findings do not always apply, and their absence

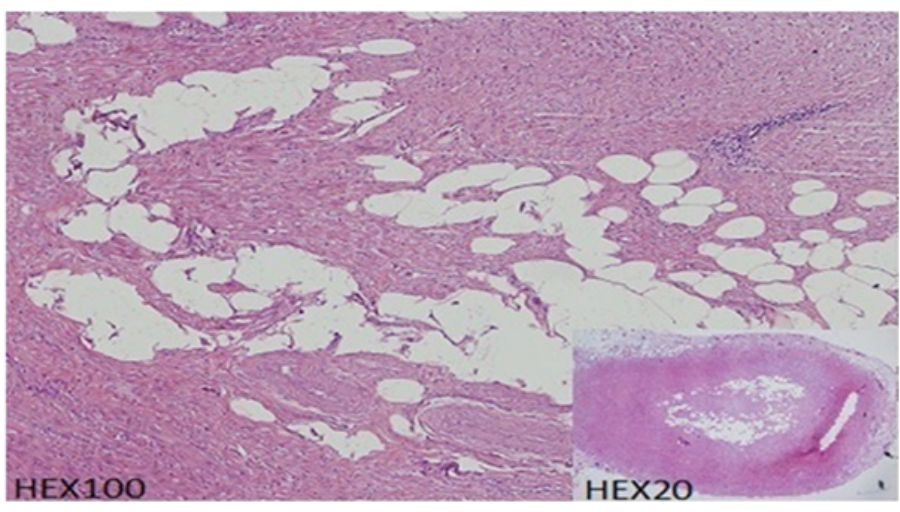

Figure 1. Cronic inflammatorial cells mixed with with poliferations of fusiform cells filling almost the entire lumen are seen on a fibromyxoid basement. should not make clinicians move away from acute appendicitis (3).

It is believed that the obstruction of appendix lumen is the initiating event for acute appendicitis. Such an obstruction can be brought about by hardened feces (fecalith), lymphoid hyperplasia, or some foreign materials. Among these, most common cause is the partial or complete lymphoid obstruction of the lumen. Luminal obstruction gives rise to excessive bacterial proliferation and increased mucus secretion, which in turn leads to an increase in luminal pressure with resulting lymphatic and venous obstruction. Bacterial overproliferation generates edema and an acute inflammatory response. As a result, appendix becomes edematous and ischemic; necrosis and perforation may appear with time, worsening the clinical condition (2).

Several recent case reports have suggested a role of neural component in its pathophysiology. Such cases are encountered in the form of obliterated appendix, fibrous obliteration, appendiceal neuroma, and neurogenic appendicitis. These cases constitute approximately $0.04 \%$ to $4.2 \%$ of cases operated with a preliminary diagnosis of appendicitis. Recurrent inflammatory attacks in an obliterated appendix are thought to cause the appearance of clinical signs and symptoms of acute appendicitis by leading to the proliferation of neuroendocrine cells found in the stroma of appendix. It was formerly believed that the causative factor for obliteration is fibrosis, and obliterated appendix and fibrous obliteration used to be used synonymously. In a 1397-case appendectomy series, Diniz et al. reported an obliterated appendix rate of $4.2 \%$, showing that neural hyperplasia were more common in obliterated appendices (4). Koksal and Akin (5) found an appendiceal neuroma rate of $1.6 \%$ in a study comprising 581 cases; they reported that appendiceal neuromas had similar clinical and laboratory findings with acute appendicitis. They also observed a predominancy of neuroendocrine cell proliferation in histological examination.

In a series composed of 237 cases, Olsen and Holck (6) determined an obliterated appendix rate of $22 \%$ in routine appendectomy specimens and $58 \%$ in autopsy materials. The authors attributed this difference to the fact that the autopsy cases were of advanced age; they advocated that not only obliteration, but also neurogenic hyperplasia increase in rate with age, and silent inflammatory attacks cause hyperplasia in neurogenic tissue and argyrophilic cells in addition to fibrosis. 
In conclusion, neural hyperplasia is a common finding in obliterated appendicitis, and it is now understood that most cases formerly designated different names are actually appendiceal neuroma. In appendiceal neuromas which are rare and diagnosed as appendicitis when they cause acute abdomen, the recommended treatment is surgery and it is the same as the routine surgical procedure applied in acute appendicitis. The definitive diagnosis is made by histopathological examination.

Conflict of interest: Authors declare that there is no conflict of interest between the authors of the article.

Financial conflict of interest: Authors declare that they did not receive any financial support in this study.

Address correspondence to: Mehmet Tolga Kafadar, Health Sciences University Mehmet Akif Inan Training and Research Hospital Clinic of General Surgery, Şanlıurfa, Turkey e-mail: drtolgakafadar@hotmail.com

Tel: + 904143186000 Fax: + 904143186707

\section{REFERENCES}

1. Hardin MD. Acute appendicitis: Review and update. Am Fam Physician 1999;60:2027-34.

2. Marudanayagam R, Williams GT, Rees BI. Review of the pathological results of 2660 appendicectomy specimens. J Gastroenterol. 2006;41:745-9.

3. Fales WD, Overton DT. In: Tintinalli JE, ed. A study in emergency medicine. 4th ed. Dallas: Mc Graw-Hill,1996:217.

4. Diniz G, Üstün M, Çengel G, et al. Is neurogenous hyperplasia a cause of appendiceal obliteration? (A retrospective study of 1397 cases). ADU Tıp Fakültesi Derg 2001; 2: 15-8.

5. Köksal H, Akın N. Appendiceal neuromas: Retrospective clinical analysis. Kolon Rektum Hast Derg 2009;19:118-21.

6. Olsen BS, Holck S. Neurogenous hyperplasia leading to appendiceal obliteration: An immunohistochemical study of 237 cases. Histopathology 1987;11:843-9. 